\title{
Retraction Note: Predicting new molecular targets for rhein using network pharmacology
}

Aihua Zhang ${ }^{1,2}$, Hui Sun ${ }^{1,2}$, Bo Yang ${ }^{1,2}$ and Xijun Wang ${ }^{1,2^{*}}$

\section{Retraction}

The Editors regretfully retract the article [1] as we believe the peer-review process was compromised and inappropriately influenced by the authors. Following further post-publication peer review the Editors no longer have confidence in the soundness of the findings. We apologise to all affected parties for the inconvenience caused.

Received: 12 August 2014 Accepted: 14 August 2014

Published: 18 September 2014

\section{Reference}

1. Zhang A, Sun H, Yang B, Wang X: Predicting new molecular targets for rhein using network pharmacology. BMC Syst Biol 2012, 6:20.

* Correspondence: xijunwangls@126.com

${ }^{1}$ National TCM Key Lab of Serum Pharmacochemistry, Heilongjiang University, of Chinese Medicine, Heping Road 24, Harbin 150040, China

${ }^{2}$ Key Pharmacometabolomics Platform of Chinese Medicines, Heping Road 24, Harbin 150040, China

\section{Submit your next manuscript to BioMed Central} and take full advantage of:

- Convenient online submission

- Thorough peer review

- No space constraints or color figure charges

- Immediate publication on acceptance

- Inclusion in PubMed, CAS, Scopus and Google Scholar

- Research which is freely available for redistribution

Submit your manuscript at www.biomedcentral.com/submit 